$1-1-2011$

\title{
Prerequisites in behavioral science and business: opportunities for dental education.
}

\author{
David G. Dunning \\ University of Nebraska Medical Center, ddunning@unmc.edu \\ Brian M. Lange \\ University of Nebraska Medical Center, blange@unmc.edu \\ Robert D. Madden \\ University of Nebraska Medical Center \\ Koko K. Tacha \\ University of Nebraska Medical Center
}

Tell us how you used this information in this short survey.

Follow this and additional works at: https://digitalcommons.unmc.edu/cod_articles

Part of the Dentistry Commons

\section{Recommended Citation}

Dunning, David G.; Lange, Brian M.; Madden, Robert D.; and Tacha, Koko K., "Prerequisites in behavioral science and business: opportunities for dental education." (2011). Journal Articles: College of Dentistry. 5 . https://digitalcommons.unmc.edu/cod_articles/5

This Article is brought to you for free and open access by the College of Dentistry at DigitalCommons@UNMC. It has been accepted for inclusion in Journal Articles: College of Dentistry by an authorized administrator of DigitalCommons@UNMC.For more information, please contact digitalcommons@unmc.edu. 


\title{
Prerequisites in Behavioral Science and Business: Opportunities for Dental Education
}

\author{
David G. Dunning, Ph.D.; Brian M. Lange, Ph.D.; Robert D. Madden, D.D.S., M.B.A.; \\ KoKo K. Tacha, B.S.
}

Abstract: There is increasing pressure on recent dental school graduates to understand and successfully utilize patient management and business management strategies to run a productive dental office. Dental schools are faced with the dilemma to either add more credit hours in their already crowded curriculum or adjust predental school requirements. All fifty-nine U.S. dental schools were assessed online to determine admission requirements in the areas of behavioral science and business education. Results show that only 11.9 percent of the schools require prerequisite coursework in behavioral science and no school requires prerequisite coursework in business. However, 64.4 percent and 30.5 percent of schools encouraged or recommended prerequisite coursework in behavioral science and business, respectively. We suggest that the dental education community involve key stakeholders to discuss the incorporation of prerequisite coursework in behavioral science and business. Additional courses in these disciplines would provide dental students better backgrounds from which the dental curriculum could build a more advanced and applied perspective to better prepare students for practice.

Dr. Dunning is Professor, Department of Oral Biology, College of Dentistry, University of Nebraska Medical Center; Dr. Lange is Professor, Department of Oral Biology, College of Dentistry, University of Nebraska Medical Center; Dr. Madden is a Private Practitioner, Southwest Family Dentistry, Littleton, CO; and Ms. Tacha is a fourth-year dental student, College of Dentistry, University of Nebraska Medical Center. Direct correspondence and requests for reprints to Dr. David Dunning, Department of Oral Biology, College of Dentistry, University of Nebraska Medical Center, 40th and Holdrege Streets, Lincoln, NE 68516;

402-472-1325 phone; 402-472-2551 fax; ddunning@unmc.edu.

Keywords: dental admissions criteria, behavioral science, curriculum, dental education, business, practice management

Submitted for publication 3/16/10; accepted 7/16/10

$\mathrm{J}$ ohn Dewey wrote in 1916 that "the aim of education is to enable individuals to continue their education [and] the object and reward of learning is continued capacity for growth."1 This astute observation by the philosopher and psychologist captures the essence of lifelong learning, a goal acculturated in dental education as an accreditation standard. ${ }^{2}$ We are reminded that Dewey emphasized, among other points, the importance of life experiences as part of the educational process. Benjamin Franklin once observed, on the other hand, that "experience is a dear teacher, but fools will learn at no other," ${ }^{3}$ resulting in a more balanced view of the importance of both formal education and the informal education of life itself. The interplay of formal education and the informal lessons of life is arguably nowhere more self-evident than in the daily application of behavioral science and business acumen in dental practice. In a given day, a dentist may have to manage a fearful patient, give formative feedback to a staff member with marginal performance, monitor accounts receivable, converse with a third-party payer about delayed reimbursement, and comply with a myriad of government regulations. Clearly, behavioral science and business skills are vital to the success of a practicing dentist. It is also evident that teaching these domains and related skills to students who tend to be focused, by necessity, on basic sciences and clinical skills presents some unique challenges and opportunities for dental educators.

This new decade has ushered in significant changes in national health care policy and delivery systems as well as economic challenges. ${ }^{4-6}$ How these changes and challenges will ultimately impact our dental students and dental practice remains to be seen. However, in aggregate, increased government involvement in health care, various "mid-level" provider delivery systems, and taxing economic conditions will likely require even more behavioral science and business skills than ever before. As Levin 
recently observed, "Dentists are thinking more like business people" in these changing times. ${ }^{7}$ Willis reinforced the same sentiment related to business: "The study and teaching of the discipline of dental practice management are becoming more important as the dental practice business environment becomes increasingly complex. Changes in the external environment of dental practice require that practice owners have more of a business orientation in managing their practices than ever before" (p. 1145). ${ }^{8}$ Meanwhile, particularly in the area of business instruction, dental students and graduates consistently express a need for more education, ${ }^{9,10}$ saying, in effect, "I am not prepared to manage a dental practice."

Furthermore, it appears that most dental students have a limited background in behavioral science and even less education in business, based on consistent even if anecdotal observations from dental educators. In addition, data from three consecutive dental classes at our institution indicate that students have, on average, about six to nine semester credit hours of undergraduate instruction in behavioral science courses, although in each class several students have no coursework in behavioral science. Business course background is even more absent, with approximately one-third of class members having taken no courses and another third having taken one or two courses. Willis affirms that a typical dental student has a background lacking in business knowledge and that few dental schools have any entrance requirements related to business or economics. ${ }^{8}$ Interestingly, the American Dental Association's survey of dental education admission standards does not mention "behavioral science" or "business," suggesting that these domains have little bearing on admissions standards. ${ }^{11}$

We would like to expand the current "dialogue going on about the state of predoctoral dental education and the need for curriculum change" ( $p$. $135)^{12}$ to include prerequisites in behavioral science and business. In order to develop a more informed perspective on this topic, we reviewed prerequisite requirements in all U.S. dental schools in the domains of behavioral science and business, both broadly and liberally defined. Specifically, we sought to answer two fundamental questions: 1) Do dental schools encourage predental students to take behavioral science courses or business courses? and 2) Do dental schools require behavioral science courses or business courses as prerequisites and, if so, how many semester credit hours and what specific courses?

\section{Methods}

The published and publically accessible online admissions requirements of all fifty-nine U.S. dental schools were accessed in December 2009 and January 2010. Admissions requirements for all schools were available online, with general disciplines and specific course requirements listed. In approximately 30 percent of the cases, additional information was provided in supplemental pages such as frequently asked questions. For the purpose of this study, "behavioral science" was defined very liberally to include courses in the disciplines of psychology (introductory courses, general courses), sociology, communication, speech, and anthropology. We readily acknowledge that it is debatable about whether a given course in a given discipline (for example, introduction to speech communication) is, strictly speaking, a "behavioral science" course. Similarly, "business" was defined very broadly to include courses in business communication, business law, business writing, economics, finance, marketing, accounting, management (principles, small business, human resource management), organizational behavior, leadership, and ethics.

Each author was assigned fourteen to sixteen dental schools to analyze and code information in the categories detailed in Table 1. Coding instructions with definitions and course listings for behavioral science and business were utilized by each author. Approximately 90 percent of the coding decisions were unambiguous and required no consultation with other authors: for example, "introduction to psychology" for three semester credit hours was specifically listed by a given school, or no mention whatsoever was made about business as a domain or about any business-related courses. In about 10 percent of the schools, two or more of the authors discussed how to code any ambiguous requirement in a given school. An example will demonstrate the need for collaboration. Three schools required, respectively, four, six, and twenty credit hours in social sciences and/or humanities, indicating that this requirement could be met through a combination of courses from a variety of the disciplines including sociology, psychology, political science, economics, anthropology, ethics, or more broadly "humanities or social sciences." In these three schools, no specific course or discipline-specific requirements were mandated, and thus courses in behavioral science 
Table 1. Behavioral science and business prerequisites in U.S. dental schools $(n=59)$

\begin{tabular}{lcc} 
& Behavioral Science & Business \\
\hline Courses recommended & $64.4 \%(38)$ & $30.5 \%(18)$ \\
Courses required & $11.9 \%(7)$ & 0 \\
$\begin{array}{l}\text { Required semester credit hours in psychology } \\
\text { (general, introduction to, human, applied) }\end{array}$ & $11.9 \%(7)^{\dagger}$ & 0 \\
$\begin{array}{l}\text { Specific discipline courses most commonly recommended } \\
\text { though not required }\end{array}$ & $\begin{array}{c}\text { Psychology (11, 18.6\%), } \\
\text { sociology (8, 13.6\%), } \\
\text { communication (8, 13.6\%) }\end{array}$ & $\begin{array}{c}\text { Accounting (6, 10.2\%), } \\
\text { econics }(6,10.2 \%), \\
\text { management }(5,8.5 \%)\end{array}$ \\
${ }^{+}$One school also required 3 hours in sociology in addition to 3 hours in psychology. &
\end{tabular}

and business were coded as being recommended or encouraged but not required. All similar instances of ambiguous coding were resolved through a conference with two authors until reaching consensus.

\section{Results}

Table 1 summarizes the prerequisites in behavioral science and business in U.S. dental schools. Thirty-eight of fifty-nine (64.4 percent) dental schools recommended or encouraged students interested in pursuing application to their dental schools to take courses in behavioral science. Only seven (11.9 percent) both encouraged and required prerequisite coursework in behavioral science, ranging from two to four semester credit hours in psychology in six schools and a seventh school requiring three semester hours in both psychology and sociology. Eleven schools (18.6 percent) recommended courses in psychology, eight (13.6 percent) recommended courses in sociology, and eight (13.6 percent) recommended courses in communication. Four schools ( 6.8 percent) included a general composite credit hour requirement in social science and/or humanities that could but did not have to include specific courses in behavioral science.

Only eighteen of the fifty-nine (30.5 percent) dental schools recommended coursework in business. No school required any business courses as a specific prerequisite. Business courses most often recommended were accounting (6/59 or 10.2 percent), economics (6/59 or 10.2 percent), and management (5/59 or 8.5 percent). In one school, economics could be included in a composite list of twenty credit hours but was not required. In another school, business writ- ing could be included but was not required as part of a larger English credit hour requirement.

\section{Discussion and Suggestions}

The role of predoctoral dental education in relieving pressure from the dental school curriculum requires continued consideration. Accreditation standards and the revised competencies developed through the American Dental Education Association (ADEA)'s Council of Sections disproportionately emphasize both behavioral science and practice management in light of assigned faculty and curricular time. In view of scarce resources, it may be an opportune time to "download" some instruction in behavioral science and business to the level of prerequisites in order to maximize the limited faculty and curricular time available in dental schools. Willis acknowledges the challenges of teaching toward competence in practice management with limited faculty and curricular time assigned in this discipline. ${ }^{8}$ The same can certainly be observed about behavioral science competencies.

In consideration of the results, we strongly encourage the dental education community to begin discussions about the possibility of adding prerequisites in behavioral science and business. Key stakeholder groups within ADEA should be represented in deliberations about changing prerequisites, including the Council of Sections - particularly the sections on academic affairs, dental school admissions officers, behavioral science, and practice management - and the Council of Students. Leaders selected from each group could be identified to participate in an initial task force to discuss and recommend possible new 
prerequisites in behavioral science and business. Dental school admissions officers could survey their section members about any planned changes in prerequisites, including courses in behavioral science and business.

Predental advisors would eventually need to be informed about any recommended changes in prerequisites. This would be an opportunity for the dental education community to orient predental advisors about the importance of personal and professional development of predental students.

We suggest two cornerstone criteria to guide discussions regarding dental school admissions requirements in behavioral science and business. First, prerequisites should serve to build a solid foundation upon which applied dental college instruction can build. If students learn some basic concepts and skills related to behavioral science and business, dental faculty members presumably can refresh this student background and move more quickly amidst a very crowded curriculum into applied and deeper instruction. Second, being very conscious of student indebtedness, recommendations should not increase student debt. Most if not all dental schools require ninety or more undergraduate credit hours and commonly include upwards of twenty to forty semester course hours as elective options. In other words, recommendations for adding behavioral science and business courses as prerequisites should be discussed within the general framework of credit hour prerequisites in dental schools.

As part of the deliberations, the dental education community may wish to embrace what several dental schools have already done - namely, including an introduction to psychology/general psychology of at least three to four semester credit hours as a prerequisite. These additional courses could also be included as possible prerequisites: an introduction to human communication or, preferably, health communication in a course of three to four semester credit hours (with some required public speaking experiences), and three to four more credit hours from among small group process/decision making, abnormal psychology, interpersonal relationships, social psychology, sociology, or persuasion/motivation.

Having students with such a background, behavioral science faculty members in dental schools could concentrate on topics and skills specifically focusing on patient and staff communication/management instead of having to first teach foundational concepts such as positive reinforcement and mentored behavioral change. Henzi et al. noted that large portions of the dental curriculum are perceived by students "as being of questionable relevance and most of these courses were in the biomedical, behavioral, and social sciences." ${ }^{.13}$ This student perception of behavioral and social sciences may develop for many reasons, including relative lack of student background in the general domain as well as the lack of application to the patient/clinical context. Establishing a minimal baseline of coursework in behavioral science and encouraging faculty members to build on this background through applied teaching content could potentially improve student perceptions of the relevance of behavioral science instruction in dental schools.

With dental schools increasingly under budgetary constraints, the dental education community could also consider adding these business courses as prerequisites: an introduction to management or an organizational behavior course of three to four semester credit hours; a personal finance course of two to three semester hours; and three to four additional credit hours from among small business management, economics, marketing, accounting, or strategic management. Significantly, because of excessive demand some business schools may prevent non-business majors from taking courses in their schools or limit the courses that can be taken. Therefore, some political negotiations might be necessary in some college/university systems in order for predental students to be admitted into business courses.

Finally, it should be noted that, according to ADEA's Official Guide to Dental Schools, seven dental schools offer joint D.D.S./D.M.D. and M.B.A. programs. ${ }^{14}$ The addition of prerequisites in behavioral science and business would certainly provide a foundation for students interested in pursuing these types of joint degree programs.

\section{Conclusion}

Based on the data, the vast majority of U.S. dental schools do not require sufficient prerequisites in the areas of behavioral science and basic business education. With the ever-changing economic, social, and government conditions, future dentists will need to be better prepared than ever before from a dental practice management standpoint. Due to resource constraints in dental education, the dental education community could begin deliberations to identify prerequisites to better prepare students for what they will encounter in private practice. With the increasing 
indebtedness of dental students, close attention needs to be paid to including as prerequisites courses that will prepare future dentists. As educators, we have an ethical obligation to prepare students for the future needs of the profession and its societal demands. This may necessitate changes in the way we prepare students prior to their matriculation to dental school.

\section{REFERENCES}

1. Dewey J. Democracy and education. New York: MacMillan, 1916:117.

2. Commission on Dental Accreditation. Accreditation standards for dental education programs. Chicago: American Dental Association, 2007:14

3. At: www.brainyquote.com/quotes/quotes/b/benjaminfr125395.html. Accessed: January 7, 2010

4. At: http://topics.nytimes.com/top/news/health/diseasesconditionsandhealthtopics/health_insurance_and managed_care/health_care_reform/index.html. Accessed: June 2, 2010 .

5. At: www.whitehouse.gov/issues/health-care. Accessed: June 2, 2010.

6. At: www.healthcarereform.gov. Accessed: June 2, 2010
7. Kincade K. Productivity tops list of dental trends for 2010 . At: www.drbicuspid.com/index.asp?sec $=$ ser \&sub $=$ def \& pag $=$ dis \&ItemID=303555. Accessed: January 7, 2010 .

8. Willis DO. Using competencies to improve dental practice management education. J Dent Educ 2009;73(10): 1144-52.

9. Chmar JE, Harlow AH, Weaver RG, Valachovic RW Annual ADEA survey of dental school seniors, 2006 graduating class. J Dent Educ 2007;71(9):1228-53.

10. Houlberg BJ. Dental residents' perceptions of practice and patient management training during postgraduate education. J Dent Educ 2008;72(6):643-52.

11. American Dental Association. 2008-09 survey of dental education: tuition, admission, and attrition, volume 2 . Chicago: American Dental Association, 2009.

12. Geissberger MJ, Jain P, Kluemper GT, Paquette DW, Roeder LB, Scarfe WC, Potter BJ. Realigning biomedical science instruction in predoctoral curricula: a proposal for change. J Dent Educ 2008;72(2):135-41.

13. Henzi D, Davis E, Jasinevicius R, Hendricson W. In the students' own words: what are the strengths and weaknesses of the dental school curriculum? J Dent Educ 2007;71(5):632-45.

14. American Dental Education Association. Official guide to dental schools. Washington, DC: American Dental Education Association, 2010:43-4. 